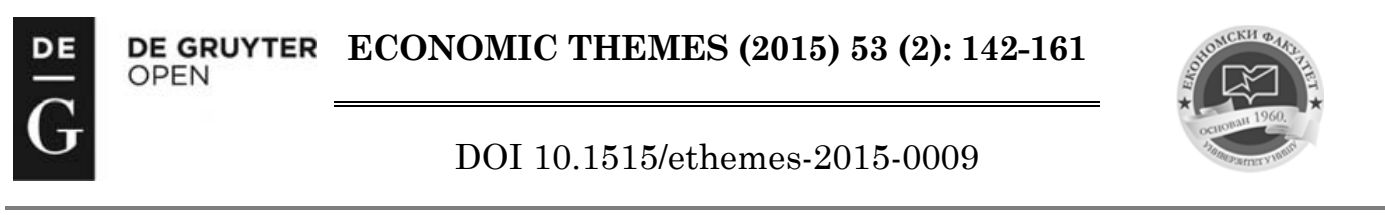

\title{
COMPARATIVE ANALYSIS OF FINANCIAL STABILITY POLICY OF THE NATIONAL BANK OF SERBIA AND THE EUROPEAN CENTRAL BANK
}

\author{
Mirjana Jemović \\ University of Niš, Faculty of Economics, Serbia \\ $\bowtie$ mirjana.jemovic@eknfak.ni.ac.rs \\ Borko Krstić \\ University of Niš, Faculty of Economics, Serbia \\ $\bowtie$ borko.krstic@eknfak.ni.ac.rs \\ UDC \\ 336.711 \\ (497.11:4-672EU \\ Review paper

\begin{abstract}
The Republic of Serbia has successfully completed the first part in the European Union integration process, being granted candidate status for membership in the European Union (EU). The stage of accession negotiations is in progress, and it includes the full harmonization with the EU acquis, whereby the analytical review of legislation, the so-called screening is being carried out in 35 chapters. The global financial crisis that affected our country in 2008 has required a timely reaction of the National Bank of Serbia (NBS) in order to preserve the financial system stability, especially the banking sector as its most important segment. As the financial services sector adjusts within chapter 9, the aim of this paper is to assess the level of compliance of national legislation with the EU legislation regarding banking sector. Along with the regulatory initiatives in the field of preserving financial stability in the EU countries, the NBS has paid great attention to the harmonization of its financial stability policy with the financial stability policy of the European System of Central Banks (ESCB).
\end{abstract}

Received:

23.02.2015

Accepted:

26.06.2015
Keywords: crisis, financial stability, screening, NBS, ESCB

\section{Introduction}

The process of transition from a centralized state economy to a functioning market economy in which our country currently is, must be supported with stable and developed financial sector. Since in our country the National Bank of Serbia is in jurisdiction over the operations of banks and certain key non- 
banking financial institutions (insurance companies, voluntary pension funds and leasing companies), its role in preserving financial stability is very important.

After obtaining the candidate status on March 1, 2012, the Republic of Serbia has clearly opted for the membership in the European Union, which is why in the forthcoming period obligations of meeting the Copenhagen criteria and Madrid criteria, and if it decides to enter the eurozone ${ }^{1}$ the Maastricht criteria as well, await Serbia. In such a process, the NBS plays an important role given that the realization of the mentioned criteria largely depends on its institutional capacity. The ongoing global financial crisis required a prompt response from the NBS to mitigate the consequences, and that is why this paper aims to examine the extent to which the financial stability policy of NBS is compatible with the financial stability policy of the European System of Central Banks.

\section{European Union Integration as a strategic priority of the Republic of Serbia}

EU accession is a long process, and it consists of the two mutually dependent stages: pre-accession and accession, whereby pre-accession precedes accession. Each phase consists of several sub-phases, so the EU accession comes down to the following phases: 1) opening negotiations for the conclusion of the Stabilisation and Association Agreement $(\mathrm{SAA})^{2}$; 2) signing of the SAA; 3 ) applying for the EU membership; 4) obtaining candidate status; 5) opening of accession negotiations; 6) accession negotiations; 7) closure of accession negotiations and signing the Accession Treaty; 8) ratification of the Accession Treaty in EU Member Countries; and 9) entry into force and accession to the EU (Međak \& Budimir, 2013).

The Republic of Serbia has successfully conducted the first phase in the process of EU accession by signing the SAA on 29 April 2008, thus being

\footnotetext{
${ }^{1}$ It is necessary to distinguish between the European System of Central Banks, the Eurosystem and the euro area. The European System of Central Banks (ESCB) comprises the ECB and all EU Member States which currently includes 28 states, even those that are not members of the Economic and Monetary Union of the European Union (EMU). The Eurosystem makes the ECB and 18 national central banks (Belgium, Germany, Estonia, Ireland, Greece, Spain, France, Italy, Cyprus, Latvia, Luxembourg, Malta, the Netherlands, Austria, Portugal, Slovenia, Slovakia and Finland) that have adopted the euro and thus lost their monetary sovereignty. The difference between the ESCB and the Eurosystem will exist until all EU member states do not join EMU. The eurozone can be seen at the formal and informal level. In formal terms, the eurozone includes $18 \mathrm{EU}$ member states, while at the informal level, it includes countries that are not EU members, and which have accepted the euro as its currency (ie. Montenegro).

${ }^{2}$ It is the Stabilisation and Association Agreement that has offered a secure European perspective to the countries in the Western Balkans - Croatia, Bosnia and Herzegovina, Serbia, Montenegro, Albania and Macedonia.
} 
granted the status of a country associated with the European Union, with the clear EU membership perspective. EU membership is conditioned by meeting the relevant criteria defined at the EU Summit in Copenhagen in 1993. These are the so called accession criteria, including political criteria (stability of institutions that guarantee democracy, the rule of law, human rights and respect for and protection of minorities), economic criteria (existence of a functioning market economy and capacity to cope with competition and market forces within the Union), and the obligation to accept the EU acquis (the acquis communautaire $^{3}$ ), that is, the ability to take over the obligations coming from the membership, along with accepting the aims of political, economic and monetary union. These criteria have been confirmed at the Summit in Madrid in 1995 and updated with the so called administrative and institutional criteria that highlight the importance of having an institutional and administrative capacity for effective implementation and enforcement of EU legislation (Međak \& Budimir, 2013).

After fulfilling the criteria for EU accession, the next obligation is to meet the criteria for entering the eurozone, that is, EMU. ${ }^{4}$ The criteria in question are convergence criteria, economic and legal criteria (the so called Maastricht criteria), and these criteria are to be met by all EU member countries that want to become part of the Economic and Monetary Union with euro as a common currency (Faulend, M. et al., 2005).

The economic convergence criteria imply that a country that enters the eurozone has a relatively low inflation (the average inflation rate does not exceed 1.5 percentage points above the average inflation of the three most successful EU member countries); relatively low interest rates (long-term interest rate, ie. the average nominal long-term interest rate does not exceed two percentage points above the average of the three most successful EU member countries); low level of the consolidated budget deficit (the rate of planned or realized budget deficit does not exceed $3 \%$ of gross domestic product); sustainable public debt (not more than $60 \%$ of gross domestic product); as well as a stable currency and participation in the exchange rate mechanism (the Exchange Rate Mechanism, ERM II), which means respecting the established

\footnotetext{
${ }^{3}$ This is a French term meaning, essentially, 'The EU as it is', the EU law, or a set of all treaties and laws that are binding for all the member countries within the European Union (the founding treaties and other acts derived from the contract).

${ }^{4}$ EMU now has 18 member countries who have renounced their monetary policy and accepted euro as their currency. The other 10 countries have not meet the basic convergence criteria and are Member States with a 'derogation'. Two of these, Denmark and the United Kingdom, were granted special status based on the Protocols to the Treaty on European Union, that is, the right not to adopt the euro. The 8 remaining countries: Bulgaria, Czech Republic, Croatia, Lithuania, Hungary, Poland, Romania and Sweden, in accordance with the Treaty on the Functioning of the European Union committed itself to adopt euro, which means that they must strive to fulfill all the convergence criteria.
} 
margins of fluctuation of the exchange rate, without significant variations over a period of at least two years before the introduction of the common European currency. Every two years or even earlier on the request of the EU Member Country, the Commission and the ECB are obliged to report - in the form of the Convergence Report, the Council on the progress of Member Countries in meeting the obligations in terms of the convergence criteria.

EMU accession, in addition to meeting the criteria of economic convergence, requires legal convergence also, that is, harmonization of national legislation with not only primary but with secondary EU legislation as well.

In order to better prepare for the adoption of the EU acquis and the fulfillment of the accession and convergence criteria, the Republic of Serbia adopted the National Programme for the Integration of the Republic of Serbia into the EU for the period 2008-2012 (NPI) on 9 October 2008. Hereby, Serbia has shown a willingness to harmonize its legislation with the EU acquis. ${ }^{5}$ After being granted the candidate status on 1 March 2012, the National Programme for the Adoption of the Acquis (NPAA) for the period 2013-2016 was adopted, thus achieving a continuity of the process of harmonization of legislation (European Integration Office, 2013 (SEIO)). The structure of the NPAA follows the structure of all three criteria for EU membership, which gives a clear insight into the degree of harmonization of national and European legislation.

Opening the accession negotiations with Serbia on 28 June 2013, the most demanding phase of EU integration process - membership negotiations, which implies full harmonization with the EU acquis has begun. Additional complexity of this phase is reflected in the fact that the accession negotiations are conducted in a situation when there are 28 member states of the EU and when there are signs for overcoming the economic crisis, and the still unresolved issue of the status of Kosovo and Metohija.

Analytical review of the legislation, that is screening is carried out in 35 chapters ${ }^{6}$, with the chapter being closed once they meet the criteria defined in

\footnotetext{
${ }^{5}$ In the aforementioned period, out of 1172 planned laws and regulations, 1030 were adopted

${ }^{6}$ Chapter 1: Free movement of goods; Chapter 2: Freedom of movement for workers; Chapter 3: Right of establishment and freedom to provide services; Chapter 4: Free movement of capital; Chapter 5: Public procurement; Chapter 6: Company law; Chapter 7: Intellectual property law; Chapter 8: Competition policy; Chapter 9: Financial Services; Chapter 10: Information society and media; Chapter 11: Agriculture and rural development; Chapter 12: Food safety, veterinary and phytosanitary policy; Chapter 13: Fisheries; Chapter 14: Transport policy; Chapter 15: Energy; Chapter 16: Taxation; Chapter 17: Economic and monetary policy; Chapter 18: Statistics; Chapter 19: Social policy and employment; Chapter 20: Enterprise and industrial policy; Chapter 21: TransEuropean networks; Chapter 22: Regional policy and coordination of structural instruments; Chapter 23: Judiciary and fundamental rights; Chapter 24: Justice, freedom and security; Chapter 25: Science and research; Chapter 26: Education and Culture; Chapter 27: Environment; Chapter 28: Consumer and health protection; Chapter 29: Customs Union; Chapter 30: External relations; Chapter 31:
} 
that chapter. Afterwards, the country moves on to another chapter. When it comes to the Western Balkans, chapters 23 and 24 are first to be analyzed, because the quality of the reforms carried out in all other areas depends on the quality of reforms in these two chapters. For these reasons, this chapter will remain open for the entire duration of the negotiations. This rule is applied in the negotiations with Montenegro and shall be applied to Serbia, which has so far made screening for Chapters 23 and 24, and Chapter 32 (European Commission, 2014)

The current financial crisis has to some extent shifted the focus from the financial stability policy and stressed the importance of stable business sectors of financial services for the normal functioning of the real sector of the economy. As the financial services are negotiated under Chapter 9, the next part of this paper analyzes the degree of harmonization of domestic legislation with the EU acquis in the field of banking.

\section{Harmonization of domestic banking regulations with the EU acquis}

Financial services are of great importance for the efficient functioning of the internal market of the European Union. Given the high degree of internationalization and the homogenization of financial activities, there is a trend of convergence of financial services and the transition from traditional banking to the concept of a unified financial service providers (Zavišić, 2009). In order to abolish the legal diversity in the EU financial services market, all countries aspiring to become EU members are addressed to negotiate on these matters in Chapter 9: Financial services.

This chapter analyzes the degree of compliance of national regulations with the acquis in the field of banking, insurance, pension insurance, the securities market and financial markets infrastructure, in order to assess the situation regarding the compliance of national legislation and proposed measures for the harmonization of legislation and enforcement of the acquis. Bearing in mind the specificity of Serbian financial system as a bank-oriented ${ }^{7}$, the NBS has the task to make the appropriate changes in the legislative framework governing the operations of banks in the Republic of Serbia in order to ensure its compliance with the EU acquis (European Commission, 2014).

The acquis covered by this chapter includes rules for the authorization, operation and supervision of financial institutions and regulated markets, as

Foreign, security and defence policy; Chapter 32: Financial control; Chapter 33: Financial and budgetary provisions; Chapter 34: Institutions, Chapter 35: Other issues.

7 The banking-oriented financial system (bank-centric) implies that the corporate sector is increasingly getting bank loans to finance its projects, rather than relying on instruments of the financial markets. The reverse is true in market-oriented financial systems as well. 
well as the protection of rights and informing investors. Being bank-oriented, the financial system of the Republic of Serbia has influenced this paper to analyze the degree of harmonization of domestic legislation with the acquis only for the banking sector. In this regard, the analysis includes: the rules governing the establishment and supervision of banks; preparation of annual and consolidated financial statements; control of the banking group on a consolidated basis; reorganization and bank liquidation; restructuring and recovery of the banks; and deposit insurance and investor protection. It should be borne in mind that the EU market for the purpose of free capital movement, applies two principles, respectively: the principle of a single passport, according to which a financial institution registered in one Member State is free to do business throughout the EU, without seeking special permission from the host country; and the principle of a home country rule, according to which the control of financial institutions shall be conducted by the authority of the state in which the financial institution is headquartered, which is especially important in a situation when financial institutions establishes branches or provides crossborder financial services.

Table 1. EU Acquis and the legal framework of the Republic of Serbia in the banking sector

\begin{tabular}{|c|c|}
\hline The EU acquis in the banking sector & $\begin{array}{l}\text { The legal framework of the Republic of } \\
\text { Serbia in the banking sector }\end{array}$ \\
\hline \multicolumn{2}{|c|}{$\begin{array}{l}\text { The rules on commencement and performance of activities of credit institutions and } \\
\text { prudential requirements and supervision of credit institutions }\end{array}$} \\
\hline $\begin{array}{ll}- & \text { Directive } 2013 / 36 / \mathrm{EU}^{8} \\
- & \text { EU Regulation No. } 575 / 2013^{9}\end{array}$ & $\begin{array}{l}\text { - The Law on Banks ("RS Official } \\
\text { Gazette", N0o.107/2005, No. 91/2010 } \\
\text { and 14/2015). } \\
\text { - Law on Bankruptcy and Liquidation of } \\
\text { Banks and Insurance Companies ("RS } \\
\text { Official Gazette", No. 61/2005, } \\
\text { 116/2008 and 91/2010) } \\
\text { - By-law issued under the Law on } \\
\text { Banks }\end{array}$ \\
\hline
\end{tabular}

8 Amending Council Directive 2002/87/EC and abolishing Directive 2006/48/EC and 2006/49/EC

${ }_{9}^{9}$ Amending Council Regulation No.648/2012

${ }^{10}$ The package of decisions by the help of which the Basel II standards are adopted (see page 8), as well as other decisions taken on the basis of the Banking Law: Decision on classification of balance sheet assets and off-balance sheet items ("RS Official Gazette", No.94/2011, 57/2012, 123/2012, 43/2012, 43/2013, 113/2013 and 135/2014); Decision on changes and amendments to the Decision on classification of balance sheet assets and off-balance sheet items ("RS Official Gazette", No. 135/2014); The decision on the external audit of banks ("Official Gazette" 
The legal framework for the preparation of annual and consolidated financial reports

- $\quad$ Directive $86 / 635 / \mathrm{EEC}$

- Accounting Act ("Official Gazette" No.62/2013)

- B-law ${ }^{11}$

The rules governing the supervision of a banking group on a consolidated basis

- Directive 2002/87/EC $\quad$ - Banking Law

The legal framework for the reorganization and liquidation of credit institutions

\begin{tabular}{||l|l}
\hline - Directive 2001/24 / EC & - Banking Law
\end{tabular}

The legal framework for the deposit insurance system and compensation for investors

- $\quad$ Directive 2014/49/EU ${ }^{12}$

- $\quad$ Directive 97/9/EC
- The Law on Deposit Insurance ("RS Official Gazette", no. 61/2005, No. 116/2008 and 91/2010)

- The Law on Deposit Insurance Agency ("RS Official Gazette", no. 61/2005, No. 116/2008 and 91/2010)

- Banking Law

- Law on Bankruptcy and Liquidation of Banks and Insurance Companies

- The Capital Market Act ("Official Gazette" No.31/2011)

- Regulations on Investor Protection Fund ("RS Official Gazette", No.44/12)

- Rules of Operation of the organizers of the Investor Protection Fund ("RS Official Gazette", No.84/12)

No.41/2007, 59/2008 and 67/2012); The decision to implement the provisions of the Banking Act relating to the granting preliminary approval for the establishment of a bank, the bank license and the individual consent of the NBS, as well as the establishment of criteria for determining a first class bank ("RS Official Gazette", No.43/2011 , 43/2013 and 107/2014).

${ }^{11}$ The decision on the Form and Content of the Financial Statements of Banks ("RS Official Gazette", No.71/2014 and 135/2014); The decision on the form and content of the statistical report of Banks ("RS Official Gazette", No.71/2014); The decision on the Chart of Accounts and Content of Accounts within the Chart for Banks ("RS Official Gazette", No.71/2014 and 135/2014); and the Decision on the collection, processing and dissemination of data on the status and structure of the accounts from the Chart of Accounts ("RS Official Gazette", No.71/2014 and $135 / 2014)$.

${ }^{12}$ This directive was used to revise the previous directive on deposit insurance schemes adopted 15 years ago (Directive 94/19/EC) 


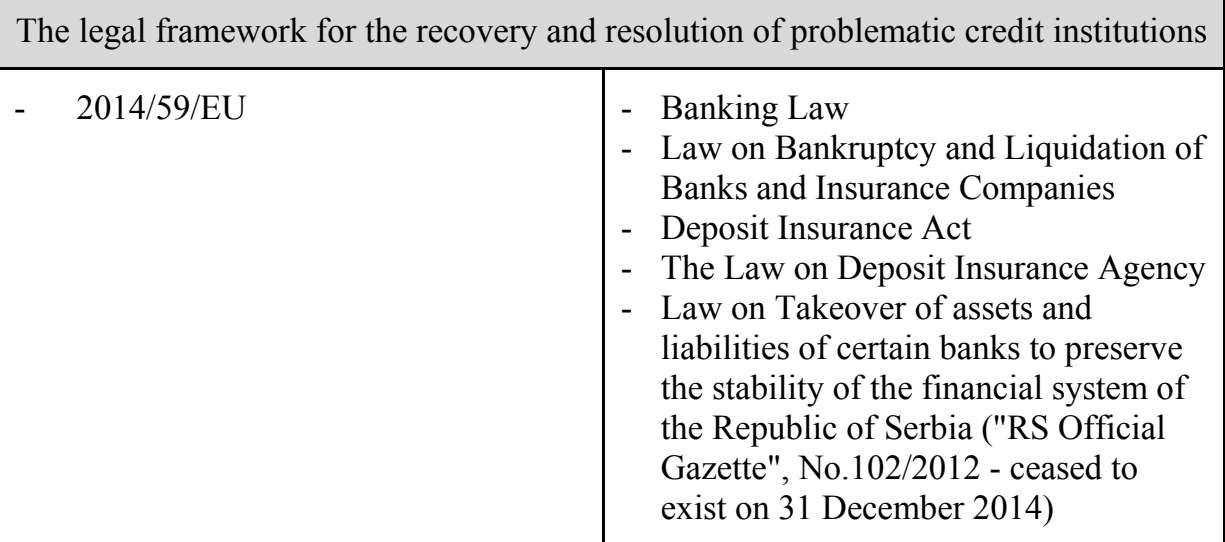

Source: table designed by: (The European Commission, 2014)

1. The legal framework regulating the procedure for establishing and functioning of banks, prudential requirements and supervision of banks: In order to assess the degree of harmonization of national regulations governing the procedure for establishing and functioning of banks as well as prudential requirements and supervision of banks with the EU acquis, first, it is necessary to briefly outline the history of the acts that previously regulated this area. The introduction of Basel II standards in the EU countries was achieved with the application and implementation of Directives 2006/48/EC and 2006/49/EC, known as the Capital Requirements Directive (CRD), and by introducing their principles into national legislation of EU member states. After the global financial crisis outbreak, the first changes to Basel II were made, and related to market risks securitization and remuneration policy. These changes were formulated in the form of Basel 2.5 standard and were approved by the adoption of CRD 2 (2009/27/EC, 2009/83/EC and 2009/111/EC) and CRD 3 (2010/76/EC). However, the key amendments of capital adequacy standards were made within the Basel III standards, in the part referring to the regulatory capital (the numerator of the indicator) (Vukovic, 2012). In addition, within Basel III, a minimum liquidity standards were introduced for the first time (Basel Committee on Banking Supervision, 2010 (Rev June 2011)).

In order to ensure the maximum harmonization of rules at the European level and limit the possibility of deviation from what is stipulated in the new legal framework, a new set of regulations on capital requirements, known as CRR and CRD $4^{13}$ (Regulation (EU) 575/2013, Directive 2013/36/EU) is adopted and its application in the EU countries will follow later this year. Such a legal framework excludes the possibility of establishing more conservative

${ }^{13}$ EU Regulations as opposed to the directives are not transposed into national regulations (laws), but are directly implemented in national legislation (translation into the language of the Member States). 
policies at the national level and provides that such rules can only be applied at the level of individual banks, that is as a result of Pillar 2 of Basel standards.

Serbia has so far ensured the application of Basel II standards, by the adoption of the package of decisions (The Decision on Capital Adequacy of Banks ${ }^{14}$; The Decision on risk management, ${ }^{15}$ The Decision on Reporting on Capital Adequacy of Banks ${ }^{16}$; The Decision on Bank Reporting Requirements ${ }^{17}$; The Decision on Disclosure of Data and Information by Banks and the Decision on the control of the banking group on a consolidated basis ${ }^{18}$, and it should be noted that with the Decision on capital adequacy of banks, the rules for calculating capital requirements for credit risk on securitization are not covered due to the lack of a legal framework and policies developed in this field in Serbia. This is the reason that neither the Basel 2.5 standard have not yet been implemented in Serbia. Their introduction is planned to be bundled with the standards of Basel III.

For the sake of gradual implementation of Basel III Standards in Serbia and harmonization of regulations on capital adequacy with Directive 2013/36/EU and Regulation (EU) 575/2013, the NBS has adopted a strategy for its gradual implementation in Serbia by the end of 2019 (National Bank of Serbia, 2013b). Since the implementation of Basel II Standards in Serbia was carried out at the time Basel III Standards had already been published, some of the elements of the Basel III Standards were already introduced into the legal system of Serbia (Matić, 2011). ${ }^{19}$ Although many developed EU countries consider the process of implementation of Basel III Standards as a great challenge, this cannot be said for Serbia, bearing in mind the current countercyclical prudential approach to supervision.

2. Financial statements and consolidated financial statements for banks and other financial institutions: Directive 86/635/EEC represents the current legal framework for the preparation of annual and consolidated financial statements of banks and other financial institutions in the EU market. With the new Law on Accounting coming into force ("Official Gazette" No. 62/2013), the NBS has adopted new by-laws, in order to achieve a greater degree of harmonization of national legislation with Directive 86/635/EEC.

\footnotetext{
14 "RS Official Gazette", No.46/2011, 6/2013 and 51/2014.

15 "RS Official Gazette", No. 45/2011, 94/2011, 119/2012, 123/2012, 23/2013 - al. decisions 43/2013 and 92/2013.

16 "RS Official Gazette", No. 45/2011 and 46/2011 - correction

17 "RS Official Gazette", No. 45/2011, 94/2011 and 87/2012.

18 "RS Official Gazette", No. 45/2011.

${ }^{19}$ a) From the definition on regulatory capital Tier 3 is excluded, that led to capital structure being reduced to Tier 1 and Tier 2; b) one additional type of capital conservation buffer was introduced with the help of which banks whose capital adequacy ratio was higher than prescribed (12\%) of less than 2.5 percentage points, could perform the distribution of profit only with elements of basic capital.
} 
3. Supplementary supervision of credit institutions, insurance companies and investment firms in a financial conglomerate: An effective supervision of the banking system, except for the supervision of individual banks includes the monitoring of the banking group, which besides banks can also include other financial institutions (Jovanić, 2006). Directive 2002/87/EC defines the rules for the effective supervision of banks and other financial institutions in the financial conglomerate. Our banking law clearly defines a banking group, the bank holding company and the powers of the NBS in the control of the banking group, and in this sense, our banking law is modern, though not in full compliance with the aforementioned EU directive. Amendments to the Law on Banks ("RS Official Gazette", No. 14/2015) are used to define a detailed plan for the recovery of the banking group (article 127a-127d), and in 2018, a new law on financial conglomerates, the one that will lead to the full harmonization with the provisions of this Directive is expected to be adopted.

4. Reorganisation and liquidation of credit institutions: This area is regulated by Directive 2001/24/EC and provides a unique procedure of liquidation in case of failure of a credit institution that operates transboundary. The national legal framework does not comply with this directive, given that in Serbia, transboundary provision of services via branches of credit institutions is not allowed (European Commission, 2014). In this sense, harmonization with the provisions of the Directive requires appropriate amendments to the Law on Banks and the Law on Bankruptcy and Liquidation of Banks and Insurance Companies.

5. Deposit insurance systems and investor compensation schemes: The deposit insurance in the Serbian market is regulated by the Law on Deposit Insurance, the Law on Deposit Insurance Agency, the Banking Law and the Law on Bankruptcy and Liquidation of Banks and Insurance Companies, and is largely aligned with the provisions of Directive 94/19/EC, and with its revision, that is Directive 2014/49/EC that regulates the matter of deposit insurance in the EU market. The discrepancies refer to the level of the insured amount, which is lower in Serbia than in Europe - the amount of insured deposit up to 50,000 euros per depositor per bank (in the EU, it amounts to EUR 100,000), as well as the starting date for the payment of the insured deposits, which in Serbia is 3 days, and in the EU 7 days from the date of the competent court decision to initiate bankruptcy or liquidation against the bank.

The legal framework guaranteeing the protection of investors in Serbia has been partly aligned with Directive 97/9/EC, which regulates this issue in the EU market. As this area is under the jurisdiction of the Ministry of Finance, the further changes to the Capital Market Law will be done in consultation with the ministry.

6. Recovery and solving of problematic credit institutions: This area is in the EU market regulated by Directive 2014/59/EU, and in the Serbian market by 
the Law on Amendments to the Law on Banks ("RS Official Gazette", No.14/2015), the Law on Bankruptcy and Liquidation of Banks and Insurance Companies, Deposit Insurance Law, the Law on the Deposit Insurance Agency and the Law on the takeover of the assets and liabilities of certain banks to preserve the stability of the financial system of the Republic of Serbia (which was in force until 31 December 2014).

A significant degree of harmonization of domestic legislation with the EU acquis in this area was realized with the amendments to the Law on Banks, whose provisions are applied from 1 April 2015. These amendments provided the full protection of the deposit owner, limited spending of the budget funds to rescue banks, and in case of financial difficulties, the shareholders are the first to bear the loss. In order for the NBS to respond in time and preserve the financial stability, the Law stipulated the introduction of the preventive mechanisms, such as the recovery plans and measures for early intervention of the banks themselves, so that they could continue with regular operations as soon as possible. Restructuring plans of banks, the NBS compiles for every bank individually, and once the "test of the lowest cost" is conducted, which should show what solution is the cheapest and most convenient for the bank.

In case of making the decision on the restructuring, the NBS may apply one of the following instruments: a) selling of shares or transfer of all or part of the assets and liabilities of the bank in restructuring to another bank, thus preserving the most important functions of banks whereas all insured depositors have access to their deposits at any time; b) the transfer of shares of the bank in restructuring or transfer of all/some parts of the assets to the special purpose bank in a situation when there is no interested bank in the market, and when the special purpose bank can neither assume liabilities that exceed its assets, nor non-performing loans; c) separation of assets, in terms of taking over nonperforming loans, which can result in higher revenues from the collection of these assets if it is run by a separate legal entity (eg. the Deposit Insurance Agency) than in the case of the revenue from the ordinary bankruptcy proceedings; d) loss allocation to the shareholders and unsecured creditors, thus leading to the cancellation of shares or reduction of their nominal value, and the conversion of creditor's demands in the shares.

The National Bank of Serbia, as the institution responsible for implementing the Law on Banks and the adoption of by-laws according to the the law, has a key role in the Negotiating Group on Financial Services. The Chair and Secretary of the Negotiating Group shall be appointed from among the representatives of the NBS and Deputy Chair and Deputy Secretary shall be appointed from among the representatives of the Ministry of Finance. Last financial crisis has revealed the extent of the consequences of the financial instability on the economy and public finances, thus central bank has recently got a role in fostering financial stability. In accordance with the European way 
of Serbia, the next part of this paper analyzes the degree of compliance of financial stability policy of NBS with the financial stability policy of the ESCB.

\section{Compatibility of financial stability policy of NBS and ESCB financial stability policy}

For the purpose of better preparation for joining the European System of Central Banks, the NBS so far has in cooperation with the European Central Bank implemented two projects: a) the first, in the period from 1 September 2008 to 31 May 2009 entitled Needs Analysis Report, and b ) the second, in the period February 2011 - December 2013 entitled "Strengthening of the Institutional Capacities of the National Bank of Serbia". The projects were used for the analysis of as many as 13 business areas ${ }^{20}$ in order to identify the areas that needed certain improvements and harmonization with the European System of Central Banks (European Integration Office, 2014).

The legal convergence is ensured by the latest amendments to the Law on the NBS ("RS Official Gazette", No.72/2003, 55/2004, 85/2005 - the Law 44/2010, 76/2012, 106/2012 and 14/2015), which ensured alignment with the Treaty on the Functioning of the European Union and the Statute of the ESCB and the ECB, with regard to establishing price stability for the basic objective of the NBS; ensuring a high level of functional, institutional, personal and financial independence of the NBS; prohibition of monetary financing and privileged access to financial institutions (Lucic, 2011).

The efforts of the NBS for faster accession of the Republic of Serbia to the EU are reflected in the fact that in this way the NBS will be able to directly participate in the preparation of regulations governing the single financial market of the EU, as well as in their full implementation through active participation in the functioning of the European institutional mechanism for preserving financial stability. It is about the adoption of the single rulebook for all financial institutions (among which there are around 8300 banks) operating in the EU member states, which significantly narrows the discretion of national regulatory authorities and contribute to the unity and comparability of the European banking market. The rules regulate the field of capital requirements (CRR, the CRD IV); Deposit Guarantee Scheme, SBS; and the resolution and recovery of the failing banks (The Bank Recovery and Resolution Directive, BRRD).

After the recent financial crisis that has affected European countries and led to the debt crisis in some of the Eurozone countries, it has become clear that

\footnotetext{
${ }^{20}$ (Financial sector supervision; legal harmonisation; liberalisation of capital movements; foreign exchange reserve management; monetary and exchange rate operations; financial services consumer protection; EU accession support; economic analysis and research; statistics; payment systems; financial stability; accounting and financial reporting; and information technology).
} 
countries with a single monetary policy must have a single financial stability policy. In this regard, in November 2014, the Banking union was formed and it currently consists of two main initiatives: the Single Supervisory Mechanism SSM and Single Resolution Mechanism - SRM. The system of deposit insurance as a potential third initiative of the banking union is missing.

The SSM and SRM are valid for the countries of the eurozone, since only these countries automatically belong to these mechanisms. Other EU member states that are not at the same time the members of the eurozone, may join the banking union by signing a close cooperation agreement with the ECB. The close cooperation means that national regulators are obliged to apply the guidelines and requirements of the ECB, because if they fail to do so in due time (not less than 48 hours, or upon notice within 15 days), the ECB may unilaterally terminate the close cooperation agreement, that is, terminate the membership of the member countries in the SSM. The membership can also be canceled by a Member State itself, but only after a three-year membership in SSM, and cannot reapply for the membership in the SSM in the following three years.

The ECB directly supervises the banks operating in the Member States of the SSM, under the following conditions: the bank assets exceed 30 billion euros or makes up more than $20 \%$ of the GDP of the Member State in which the bank is headquartered; the bank is in the top 3 of the biggest banks in the national market; the bank is granted or requested assistance from the European Stability Mechanism; there is a significant involvement of the bank in the international business (CBA Analyses, 2013). Smaller banks remain under the control of the national supervisors, and, the national supervisors are in this case under the ECB supervision, because they were somehow delegated with the supervision task. In this regard, the national supervision authorities are obliged to promptly inform the ECB on the control of these institutions, while the ECB may, if necessary, take control of any institution that operates in the Member State of the SSM.

The SRM is conceived as a mechanism for Reconstruction and recovery of the failing banks operating in the Member States of the banking union. The financing of these activities is carried out from the Single Resolution Fund, SRF, which is formed on the basis of total premiums paid by banks operating in the Member States of the SSM. The SRF earlier this year began with the development of recovery plans for certain vulnerable institutions, and it is expected to operate with its full powers from January 2016 (CBA ANALYSES, 2013). In a situation where plans for restructuring and recovery of the banks do not provide results, and the bankruptcy or liquidation is the only remaining alternative, the deposit insurance system becomes very important. However, due to many unresolved issues and a lack of harmonization of regulations regarding the deposit insurance system, and especially due to the still undefined 
relationship between the The Bank Recovery and Resolution Directive and the Deposit Insurance Fund, this element has not yet been included into the banking union.

Along with the regulatory initiatives in the field of fostering financial stability in the EU countries, the NBS has paid great attention to the harmonization of its financial stability policy with the financial stability policy of the ESCB. There are numerous forms of central banks involvement in fostering financial stability, all of which are very similar, so Smaga (2013) has introduced a Financial Stability Engagement Index in order to measure the involvement of the the 27 central banks in the European Union in ensuring financial stability. The index includes 10 components (c1 - c10), each of which takes the score "0", if the answer is "NO" or "1", if the answer is "YES".

The components are formulated as questions:

- $\quad \mathrm{c} 1$ : Does the central bank have a legal financial stability mandate?

- c2: Does the central bank have a financial stability definition?

- c3: Does the central bank publish financial stability indicators?

- c4: Does the central bank publish its own financial stability index?

- c5: Does the central bank carry out and publish the stress tests results?

- c6: Does the central bank publish reports on financial stability?

- c7: Does the central bank act as payment systems overseer?

- c8: Does the central bank act as a microprudential supervisor?

- c9: Does the central bank act as a macroprudential supervisor?

- c10: Does the central bank have a separate department responsible for analyzing financial stability?

Index construction of a Central Bank engagement in fostering financial stability is complemented based on these questions, that is, based on the positive and negative responses, a total score ranging from 0 to 10 points, depending on there being more positive or negative responses. It should be noted here that the index shows the level of involvement of a Central Bank in ensuring financial stability, but not the degree of financial stability policy in the national economy. Thus, higher index value represents only greater involvement, more analytical effort and greater commitment of the human resources by the central bank, in the area of identifying potential threats to financial stability system (Smaga, 2013).

As we have already mentioned, the central bank is the key institution in preserving and strengthening financial stability in numerous systems, although very often there is no regulatory central bank mandate. The last crisis incident has clearly showed that price stability is not enough for the overall financial stability. A stable financial system, and primarily the healthy banking sector, is a necessary precondition for a stable and efficient functioning of the financial 
sector. This is because banks are key institutions through which, a central bank transmits its monetary policy.

In a situation when a central bank was given by the law a mandate to take care of the financial system stability, its task was to clearly define financial stability, in order to know what exactly its responsibilities were. Defining the financial stability is not an easy task given the existence of a number of mutually different definitions of financial stability.

In order for the central bank to be informed about the level of financial system stability at any time, it has to calculate and publish financial stability indicators, as well as to calculate and publish financial stability index, that is, the vulnerability of the financial system. Such aggregate index would contribute to strengthen market discipline and would enable transparency of financial stability policy, considering that economic agents by monitoring this index could review the current and anticipated future financial stability, and accordingly adjust their procedures.

In order to assess the key risk indicators and vulnerability index of the financial system as a whole and financial institutions individually, as well as to assess the effects of the initial shock spread through the financial system and the real economy, a central bank conducts and publishes stress tests. They define the "weak points" in the financial system, and publishing of the stress-test results limits moral hazard, which fosters market discipline.

In order to inform all the relevant economic participants on the status of financial stability, as well as the potential risks that may threaten financial stability, the central bank publishes reports on the financial stability, which contribute to increasing transparency and strengthening domestic financial system.

Engagement of the central bank in the field of preserving and strengthening the financial stability depends on whether it conducts oversight function regarding payment system. As a payment system is a main channel of flow of funds and the transmission of monetary policy measures, it is its safety that is vital for the proper functioning of not only the financial system, but the entire economy. It is for these reasons that the central bank is authorized to regulate, control and improve the functioning of the payment system.

Central bank's involvement in microprudential and macroprudential supervision is important for financial stability. The microprudential policy and supervision take care of liquidity and solvency ratio of individual financial institutions in order to protect the interests of depositors. Taking care of a stable and sustainable operations of individual financial institutions, the central bank contributes to the overall financial stability, a sphere in which the central bank acts as a macroprudential supervisor. Seen in this way, both microprudential and macroprudential policies are complementary. However, in a situation when 
a microprudential supervision is not the responsibility of a central bank, a central bank must cooperate with the competent supervisory agencies, in order to efficiently perform its macroprudential function.

The recent financial crisis has confirmed the importance of the central bank microprudential supervision, since there was a problem of coordination and communication in the systems to which this function was delegated, and the final late reaction of the central bank. So, in order to preserve financial stability and greater efficiency of other functions that a central bank carries out (monetary regulation and last resort), it is of great importance that the central bank is authorized for microprudential supervision as well. It should be borne in mind that the implementation of these policies is mainly done by applying the same tools, and it can lead to conflict, especially in times of crisis, when macroprudential policy tends to ease regulatory requirements, while microprudential policy remains with the strict regulatory requirements.

The complexity of the task of preserving financial stability justifies the establishment of a special body responsible for these jobs, either through the establishment of an independent institution which would be fully entrusted macroprudential policy, or through establishment of joint bodies in the form of a board or committee, which would be composed of representatives of institutions whose activities would have an impact on the stability of the financial system. In both cases, a central bank would have the greatest responsibility in preserving and strengthening financial stability.

The NBS has qualified for each of the listed criteria of composite financial stability indicators, thus its participation in fostering financial stability has got all the high marks. Namely, in accordance with Article NO. 3 and 4 of Law on the National Bank of Serbia, the NBS has been given the responsibility for maintaining and strengthening the financial stability. Financial stability implies that the financial system (financial intermediaries, financial markets and financial infrastructure) enables efficient allocation of financial resources, both in stable operating conditions and in a crisis situation. In order to preserve financial stability, the NBS performs a number of activities, conducts regular comprehensive analysis of the macroeconomic environment and the functioning of key segments of the financial system, by publishing the financial stability report. In this way, the NBS contributes to increasing the transparency of actions and strengthening confidence in the domestic financial system, which as such supports sustainable and stable economic growth.

Amendments to Law on the NBS, adopted on 4 August and 5 November 2012 , led to forming a supervisory authority with the function to monitor microprudential supervision ${ }^{21}$. The Executive Board, on the other hand, is

${ }^{21}$ The NBS has jurisdiction in the regulation and supervision of banks, insurance companies, leasing providers and companies for managing pension funds. 
responsible for both macroprudential policy and microprudential policy. The Executive Board. therefore shares the responsibility for microprudential policy with the supervisory authority, which leads to the harmonization of these policies, particularly in the case when for the realization of their goals, the same instruments are used. Macroprudential policy has become very important in the current global financial crisis, thus being discussed separately within Chapter 17 , the one that refered to the economic and monetary affairs. The mandate of the NBS for conducting macroprudential policy and making macroprudential regulatory and other measures was set forth in Article 4, paragraph 3 of the Law on the National Bank of Serbia (National Bank of Serbia, 2013a).

For the purpose of the realization of activities which contribute to fostering and ensuring financial system of the Republic of Serbia, the NBS cooperates with other relevant national and international institutions. Within the project "Strengthening of the institutional capacities of the National Bank of Serbia (NBS)", the Vienna Initiative was reached and numerous international agreements on cooperation with other central banks and relevant institutions for the supervision of banks and other financial institutions, as well as with Deposit Insurance Agency and Bank Rehabilitation Agency (BRA) were signed. Bearing in mind the fact that the banks in Europe that have subsidiaries in the Serbian market have around $70 \%$ of the total balance sheet assets and capital of the banking sector in Serbia, this kind of cooperation is essential. The problem worsened with the escalation of the global financial crisis in the second half of 2008 , given that the danger of reducing the exposure of these banks occurred. It is for this reason that the key international financial institutions (IFIs), on the proposal of the European Bank for Reconstruction and Development (EBRD), in January 2009, established an international framework for coordination and cooperation in order to manage financial crisis - the Vienna Initiative.

The significance of the Vienna Initiative for Central, Eastern and Southeastern Europe is undeniable. It mainly allows the exchange of opinions, and then joint actions and coordination with the aim to manage financial crisis. In this way, it actively contributes to fostering financial stability in the participating countries, which increases the resistance of the national financial systems, seen as European financial system to systemic risks.

The Financial Stability Board was founded because of the need for the joint action and coordination among the institutions responsible for ensuring financial system stability in Serbia. The aim of the financial stability board was to promote and strengthen mutual cooperation between the NBS, the Deposit Insurance Agency and Securities Commission. Members of the Financial Stability Board are the Governor of the NBS, the Minister of Finance, Director of the Deposit Insurance Agency, the president of Securities Commission, Director of the Supervision of Financial Institutions, State Secretary in the Ministry of Finance, NBS Vice-Governor responsible for financial stability, as 
well as Managing Director of the Bank Supervision Department (BSD) in the NBS. Governor will be a chairperson on the meetings of the Board, which will meet at least once every three months. The Board is an advisory body whose task is to examine and assess all issues of importance to preserve the stability of the financial system and to coordinate the activities of all the key stakeholders in this process (National Bank of Serbia, 2013).

Taking care about the liquidity and solvency of the institutions that governs, the NBS becomes, if necessary, a "lender of last resort" (Marinkovic, 2008). In the situation where the bank has exhausted all prior sources of liquidity (primary and secondary liquidity reserves), and when there is no opportunity to borrow from other banks, the central bank ultimately acts as the guarantor of bank liquidity (Krstic, 2003). The conditions for such credit support are strictly defined, and as a rule, involve borrowing in the short run, with paying penalty interest (price higher than the market price) and are required to pass a quality credit assurance. The NBS with its decision on the terms of granting loans to maintain liquidity of banks has closer determined its own role as a "lender of last resort" by defining the conditions for this kind of borrowing from the central bank.

\section{Conclusion}

The previously presented arguments on the adaptation of the institutional capacity and the legislative framework of the NBS show a high degree of compatibility of our central bank with the standards and principles of the ESCB, which is a good precondition for faster EU accession, followed by the EMU accession. The role of the NBS is particularly important in the negotiation process, as well as in the economic and monetary issues, and the financial services sector. Also, its role is significant in terms of meeting the Maastricht Criteria, bearing in mind the fact that achieving and maintaining price stability policy is the main objective of the NBS.

After the global financial crisis affected European countries and led to the debt crisis in some of the Eurozone countries, it has become clear that countries with a single currency and monetary policy, must have a single financial stability policy. In that sense, in November 2014, a banking union was formed consisting of the Single Supervisory Mechanism and Single Resolution Mechanism, which furthermore created another challenge for Serbia: Should or should not Serbia access the banking union after the EU accession. The advantages are obvious, given that in this way the NBS has the opportunity to participate directly in the preparation of regulations governing the single financial market of the EU, as well as their full implementation through active participation in the functioning of the European institutional mechanism for ensuring financial stability. 
Along with the regulatory initiatives in the field of fostering financial stability policy in the EU countries, the NBS has paid great attention to the harmonization of its financial stability policy with the financial stability policy of the ESCB. As measured by the Financial Stability Engagement Index, the NBS has qualified for each of these criteria, and it has got the highest mark for its involvement in the field of fostering financial stability policy.

\section{References}

Basel Commitee on Banking Supervision (2010 (Rev June 2011)) Bazel III - A global regulatory framework for more resilient banks and banking systems.

ECB (2014) Convergence Report, dostupno na: https://www.ecb.europa.eu/pub/ convergence/html/index.en.html

Evropska komisija (2014) Republika Srbija: Izveštaj o napretku, dostupno na: http://seio.gov.rs/upload/documents/eu_dokumenta/godisnji_izvestaji_ek_o_napretk u/Izvestaj_o_napretku_dec14.pdf

Faulend, M. et al. (2005) Kriteriji Europske unije s posebnim naglaskom na ekonomske kriterije konvergencije - Gdje je Hrvatska?, Hrvatska narodna banka.

HUB ANALIZE, broj 45 (2013) Ujedinjeni nadzor banaka pod okriljem ECB-a i nova pravila preustroja banaka u EU: Śto je u tome dobro za Hrvatsku?

Jovanić, T. (2006) Kontrola bankarske grupe na konsolidovanoj osnovi: ovlašćenja nadzornog organa sa aspekta prudencione kontrole i saradnja regulatornih tela, Bankarstvo, 5-6: 20-30.

Kancelarija za evropske integracije (2014) Nacionalni program za usvajanje pravnih tekovina Evropske unije, dostupno na: http://www.seio.gov.rs/upload/documents/ nacionalna_dokumenta/npaa/npaa_2014_2018.pdf

Krstić, B. (2003) Bankarstvo, Ekonomski fakultet, Univerzitet u Nišu.

Lučić, L. (2011) Evropska monetarna unija i Srbija, Bankarstvo, 9-10: 52-75.

Marinković, S. (2008) Finansijsko tržište i finansijske institucije u Republici Srbiji, Ekonomski fakultet, Univerzitet u Nišu.

Matić, V. (2011) Bazel III - izmenjeni koncept kapitala, Bankarstvo, 7-8: 172-178.

Međak, V., Budimir, B. (2013) Vodič kroz pristupanje Srbije Evropskoj uniji. Beograd: ISAC Fond.

Narodna banka Srbije (2013a) Godišnji izveštaj o stabilnosti finansijskog sistema.

Narodna banka Srbije (2013b) Strategija za uvođenje standarda Bazel III u Srbiji, dostupno na:http://www.nbs.rs/export/sites/default/internet/latinica/55/55_2/55_2_7/ Strategija_BazelIII.pdf

Smaga, P. (2013) Assesing involvement of central banks in financial stability. Center for financial stability Policy paper, dostupno na: http://www.centerforfinancialstability.org/ research/Assessing_052313.pdf

Vuković, D. (2012) Bazel III - nenameravane posledice, Bankarstvo, 2: 24-33.

Zakon o NBS, Službeni glasnik RS, br. 72/2003, 55/2004, 85/2005 - dr. zakon, 44/2010, 76/2012,106/2012 i 14/2015.

Zakon o bankama, Službani glasnik RS, br. 107/2005, 91/2010 i 14/2015.

Zavišić, A. (2009), U susret jedinstvenom finansijskom tržištu Evropske unije. Bankarstvo, 1-2: $42-65$. 


\title{
KOMPARATIVNA ANALIZA POLITIKE FINANSIJSKE STABILNOSTI NARODNE BANKE SRBIJE I EVROPSKE CENTRALNE BANKE
}

\begin{abstract}
Apstrakt: Republika Srbija je uspešno okončala prvu etapu u procesu priključenja Evropskoj uniji, dobijanjem statusa kandidata za članstvo u Evropsku uniju (EU). U toku je faza pristupnih pregovora, koja podrazumeva potpuno usaglašavanje sa pravnom tekovinom EU, pri čemu se analitički pregled zakonodavstva, tj. skrining sprovodi u 35 tematskih poglavlja. Globalna finansijska kriza koja je zahvatila našu zemlju 2008. godine zahtevala je pravovremenu reakciju Narodne banke Srbije (NBS) u cilju očuvanja stabilnosti finansijskog sistema, posebno bankarskog sektora kao njegovog najznačajnijeg segmenta. Kako se oblast finansijskih usluga usklađuje u okviru Poglavlja 9, rad ima za cilj da oceni stepen usaglašenosti domaćeg zakonodavstva sa evropskim u oblasti bankarskog sektora. Uporedo sa regulatornim inicijativama na polju očuvanja finansijske stabilnosti u zemljama EU, NBS je veliku pažnju posvetila usklađivanju svoje politike finansijske stabilnosti sa politikom fnansijske stabilnosti Evropskog sistema centralnih banaka (ESCB).
\end{abstract}

Ključne reči: kriza, finansijska stabilnost, skrining, NBS, ESCB 